\title{
ANÁLISE DA QUALIDADE AMBIENTAL URBANA
}

\author{
analysis of urban environmental quality \\ Cíntia Minaki* \\ Margarete Cristiane de Costa Trindade Amorim**
}

\begin{abstract}
Resumo
Com o intenso processo de urbanização no Brasil, a qualidade ambiental apresenta-se como um fator de extrema importância para avaliar as condições que os espaços urbanos podem ofertar à população. Nesse sentido, este trabalho buscou verificar alguns indicadores ambientais urbanos em Guararapes, localizada no noroeste paulista, com o objetivo de avaliar a sua qualidade ambiental, visando a contribuir para as estratégias de seu desenvolvimento. Os indicadores utilizados foram o uso inadequado do solo, as atividades potencialmente poluidoras, as enchentes, as áreas de ocorrência de temperaturas mais elevadas, a insuficiência de cobertura vegetal arbórea, a alta densidade de edificações e os espaços livres de edificação sem cobertura vegetal. A partir do mapeamento desses indicadores, houve a sobreposição dos mesmos e a elaboração da carta síntese de qualidade ambiental urbana, adaptando-se à metodologia de Nucci $(1996,2001)$. Em algumas áreas da cidade, registrou-se a ocorrência de até quatro indicadores negativos, demonstrando que, mesmo se tratando de uma cidade de pequeno porte, suas características de ocupação são suficientes para gerar queda na qualidade ambiental. Neste trabalho, também foi possível a proposição de ideias para melhorar a qualidade desses espaços, sob o enfoque do Planejamento da Paisagem.
\end{abstract}

Palavras-chave: Qualidade Ambiental Urbana, Carta de Qualidade Ambiental, Guararapes.

\section{Abstract}

Due to the intense process of urbanization in Brazil, the environmental quality is presented as a fundamental issue to evaluate the conditions offered by urban spaces. In this sense, this work tried to verify some urban environmental indicators in Guararapes, located in the northwest of the state of São Paulo, with the aim to examine its environmental quality and to contribute to the strategies of its development. The indicators used were the inappropriate use of the soil, the potentially polluting activities, the floods, the areas of occurrence of higher temperatures, the insufficiency of arboreal coverage, the high density of buildings and open spaces of building without vegetation cover. After the mapping of these indicators, a synthesis map of urban environmental quality was drawn, adapting it to the methodology of Nucci $(1996,2001)$. In some areas of the city, it was registered up to four negative indicators, demonstrating that, even in a small town, its characteristics of occupation are sufficient to generate the drop of environmental quality. In this paper, it was also possible to propose ideas for improving the quality of these areas, by the point of view of the Landscape Planning.

Key words: Urban environmental quality, Environmental quality map, Guararapes.

\section{Resumen}

Con el intenso proceso de urbanización en Brasil, la calidad del medio ambiente se presenta como un factor extremadamente importante para evaluar las condiciones que los espacios urbanos pueden ofrecer a la población. En este sentido, este trabajo tuvo como objetivo verificar algunos de los indicadores ambientales urbanos en Guararapes, situada en el noroeste de São Paulo, con el fin de evaluar su calidad ambiental, con el objetivo de contribuir a sus estrategias de desarrollo. Los indicadores utilizados fueron el uso inadecuado del suelo, las actividades potencialmente contaminantes, inundaciones, áreas de ocurrencia de temperaturas más altas, la falta de cobertura forestal, la alta densidad de edificios y espacios sin edifício y sin cobertura vegetal. A partir de la cartografía de estos indicadores, se produjo una sobreposición de los mismos y la preparación de la carta síntesis de la calidad del medio ambiente urbano, una adaptación de la metodología de Nucci (1996, 2001). En algunas zonas de la ciudad, registró la ocurrencia de un máximo de cuatro indicadores negativos, mostrando que, a pesar de ser una pequeña ciudad, sus características de la ocupación son suficientes para generar una disminución en la calidad ambiental. En este trabajo, también fue posible proponer ideas para mejorar la calidad de estos espacios, desde el punto de vista de la Planificación del Paisaje.

Palabras clave: Calidad del Medio Ambiente Urbano, Carta de la Calidad Ambiental, Guararapes.

(*) Doutoranda da Pós-Graduação em Geografia da Universidade Estadual Paulista Júlio de Mesquita Filho, Presidente Prudente - Rua Roberto Simonsen, 305, CEP: 19.060-900, Presidente Prudente (SP) - Brasil. Tel: (+55 18) 32295375 - cminaki@gmail.com

(**) Bolsista Produtividade do CNPq. Prof ${ }^{\mathrm{a}}$. Dra . da Pós-Graduação em Geografia da Universidade Estadual Paulista Júlio de Mesquita Filho, Presidente Prudente - Rua Roberto Simonsen, 305, CEP: 19.060-900, Presidente Prudente (SP) - Brasil. Tel: (+55 18) 32295375 - mccta@fct.unesp.br 


\section{INTRODUÇÃO}

O desenvolvimento urbano emerge como um tema intensamente discutível sob o enfoque ambiental, em decorrência da existência e da expansão das cidades. Isso contribui para o surgimento de uma prerrogativa quase imutável: não há como refletir acerca do ser humano sem levar em consideração o seu habitat produzido e constantemente impactado.

Nesse cenário, a qualidade de vida surge como um princípio de bem-estar que, embora não seja respeitado nas cidades, vem ganhando, cada vez mais, a atenção de estudiosos.

A terminologia qualidade de vida, que é de fácil compreensão, mas de difícil consenso em termos da formulação de um conceito, foi mencionada pela primeira vez por Pigou em 1920, em uma abordagem sobre economia e bem-estar. Porém, depois disso, foi esquecida, retornando o seu uso a partir da segunda metade do século XX (KLUTHCOVSKY; TAKAYANAGUI, 2007, p. 14).

Apesar de apresentar uma ligação intrínseca com a área da saúde, o termo vem sendo bastante utilizado por outras áreas do conhecimento, sendo uma delas a Geografia. É possível, a partir dessa extensão, abranger um indicador de qualidade de vida, que é a qualidade ambiental. "É inegável que a qualidade do meio ambiente no qual vivemos, trabalhamos e divertimos, influi consideravelmente na própria qualidade de vida" (MACHADO, 1997, p. 17). A dimensão ambiental, por sua influência na vida humana, torna-se um aspecto de essencial preservação.

Refletindo sobre o caráter espacial, a qualidade ambiental urbana é diferente da qualidade ambiental rural, considerando as peculiaridades dessas paisagens, principalmente as características de ocupação, infraestrutura, estado da vegetação, presença de recursos naturais e produção de recursos antrópicos. Não obstante existam particularidades entre o rural e o urbano, a qualidade ambiental tem uma finalidade comum, que é a da busca por um espaço que proporcione maior proximidade entre o homem e a natureza, visando ao seu conforto.

Uma vez que, segundo o Instituto Brasileiro de Geografia e Estatística (IBGE), 84\% da população brasileira vive nas cidades, entende-se como necessária a avaliação da qualidade ambiental nesses espaços mais ocupados. Ainda de acordo com o Censo Demográfico de 2010, são 5.565 municípios, dos quais quase $95 \%$ possuem até 100.000 habitantes e menos de $0,7 \%$ possuem mais de 500.000 habitantes. Logo, a preocupação com as cidades de até 100.000 habitantes deve crescer nos estudos voltados à gestão e ao planejamento urbano.

$\mathrm{Na}$ Geografia, foram muitos os enfoques na questão ambiental na segunda metade do século XX, podendo-se citar Monteiro (1981) e Christofoletti et al. (1995), mas ainda não se verifica, na estrutura pública federal, um órgão que mensure e fiscalize especificamente a qualidade ambiental a partir de indicadores intraurbanos comparados.

Pode-se dizer que duas temáticas bastante consideradas pelos órgãos públicos são a qualidade do ar e da água, como os veiculados pela Companhia de Tecnologia e Saneamento Ambiental (Cetesb), e as pesquisas referentes a saneamento, divulgadas pelo IBGE, ressentindo-se pela falta de estudos relacionados ao clima urbano, à vegetação e a aspectos da infraestrutura urbana inseridos nesse tipo de análise. Além disso, a abordagem da qualidade ambiental precisa ser reconhecida pelos seus múltiplos indicadores que, conjuntamente, criam um quadro indicativo da incidência dos problemas na área urbana.

Atendendo à Lei 10.257, de 10 de junho de 2001, que regulamenta dois artigos da Constituição Federal referentes à política urbana, todos os municípios com mais de 20.000 habitantes tiveram que elaborar o seu Plano Diretor, composto pelas características de cada área, assim como pelas necessidades de planejamento em determinados setores. Na referida lei, expressões como "cidades sustentáveis", "saneamento ambiental" e "ordenação e controle do uso do solo" são utilizadas 
como diretrizes para satisfazer a política urbana de desenvolvimento. A "poluição" e a "degradação ambiental" aparecem como situações a serem evitadas na ocupação das cidades. De forma indireta, essas expressões se associam à temática aqui abordada e, embora o legislador não tenha se referido de maneira expressa à qualidade ambiental urbana, compreende-se que é um objetivo a ser alcançado pelos núcleos de ocupação.

Guararapes, localizada no noroeste paulista, com pouco mais de 30.000 habitantes, adequou-se ao Estatuto da Cidade, apresentando o seu plano diretor em 2006 (Lei municipal $n^{\circ}$ 2.347). O município possui uma economia baseada, sobretudo, nos recursos disponibilizados pelo campo, mas a maior parte de sua população se concentra na área urbana. Há uma tradicional dependência entre os limites urbano e rural, pouco manifestada nas grandes metrópoles. Entretanto, a ocupação urbana começa a se destacar por pequenas, porém constantes modificações no balanço de energia, nas edificações, na densidade populacional, criando um habitat que pode se redimensionar, intensificando problemas antes pouco constatados. Daí a necessidade de que esses estudos estimulem a prática de minimizar a queda da qualidade ambiental e sejam consonantes com o conteúdo das leis municipais.

A cidade se localiza a $21^{\circ} 16^{\prime} 35^{\prime \prime}$ de latitude sul e a $50^{\circ} 37^{\prime} 00^{\prime \prime}$ de longitude oeste, estando a sede municipal a uma altitude de 398 metros acima do nível do mar. Está inserida na $9^{\text {a }}$ Região Administrativa do Estado de São Paulo, tendo Araçatuba como município sede. Ocupa uma área de aproximadamente $957 \mathrm{~km} 2$ a noroeste do Estado, distanciando-se, aproximadamente, $493 \mathrm{~km}$ da capital paulista, tendo mais de $86 \%$ de população urbana, segundo o Censo de 2010.

O município é dividido ao meio pelo espigão mestre da bacia hidrográfica Tietê-Feio ou Aguapeí, separando as águas que, de um lado, se deslocam para a bacia do Tietê. Os rios estão sob o domínio climático tropical, apresentando predominância de chuvas de verão, e a época da cheia ocorre principalmente no período de janeiro a março.

Guararapes possui clima tropical, com verão quente e chuvoso, e inverno seco com pequena diminuição de temperatura, justificada pela atuação mais intensa de alguns sistemas frontais nessa época do ano. A concentração de precipitação ocorre de setembro a março, com temperaturas mais elevadas. Encontra-se, portanto, em área de transição entre os sistemas tropicais e polares. Não há dados de temperatura e precipitação registrados nesse município, mas, de acordo com informações do Instituto Nacional de Meteorologia (Inmet), em área próxima, mais ou menos a $21^{\circ} 40^{\prime} 43^{\prime \prime S}$ e a $49^{\circ} 44^{\prime} 33^{\prime} \mathrm{W}$, tem-se que a temperatura média máxima anual é próxima de $29,0^{\circ} \mathrm{C}$, e a temperatura média mínima anual ficou um pouco acima de $17,5^{\circ} \mathrm{C}$ no período de 1961 a 2010. Para esse mesmo período, a chuva média anual ficou em torno de $1300 \mathrm{~mm}$. (Figura 1).

O presente trabalho busca avaliar a qualidade ambiental urbana em Guararapes por meio da produção cartográfica gerada com indicadores objetivos, com o propósito de contribuir para as estratégias de seu desenvolvimento.

\section{METODOLOGIA PARA O ESTUDO DA QUALIDADE AMBIENTAL APLICADA A GUARARAPES}

A metodologia usada na pesquisa teve como base aquela proposta por Nucci $(1996,2001)$, que elaborou a Carta de Qualidade Ambiental do distrito de Santa Cecília, região metropolitana de São Paulo, a partir da sobreposição de cartas parciais, atribuindo o mesmo peso aos indicadores na avaliação da carta síntese. Como nem todos os indicadores utilizados por esse autor são adequados a cidades de pequeno porte, optou-se pelo seu modelo de estruturação do trabalho e por algumas das técnicas aplicadas.

O método utilizado foi o da Ecologia e do Planejamento da Paisagem, que permite uma abordagem sistêmica, portanto, integrada pelos elementos que compõem o sistema urbano de Guararapes. 

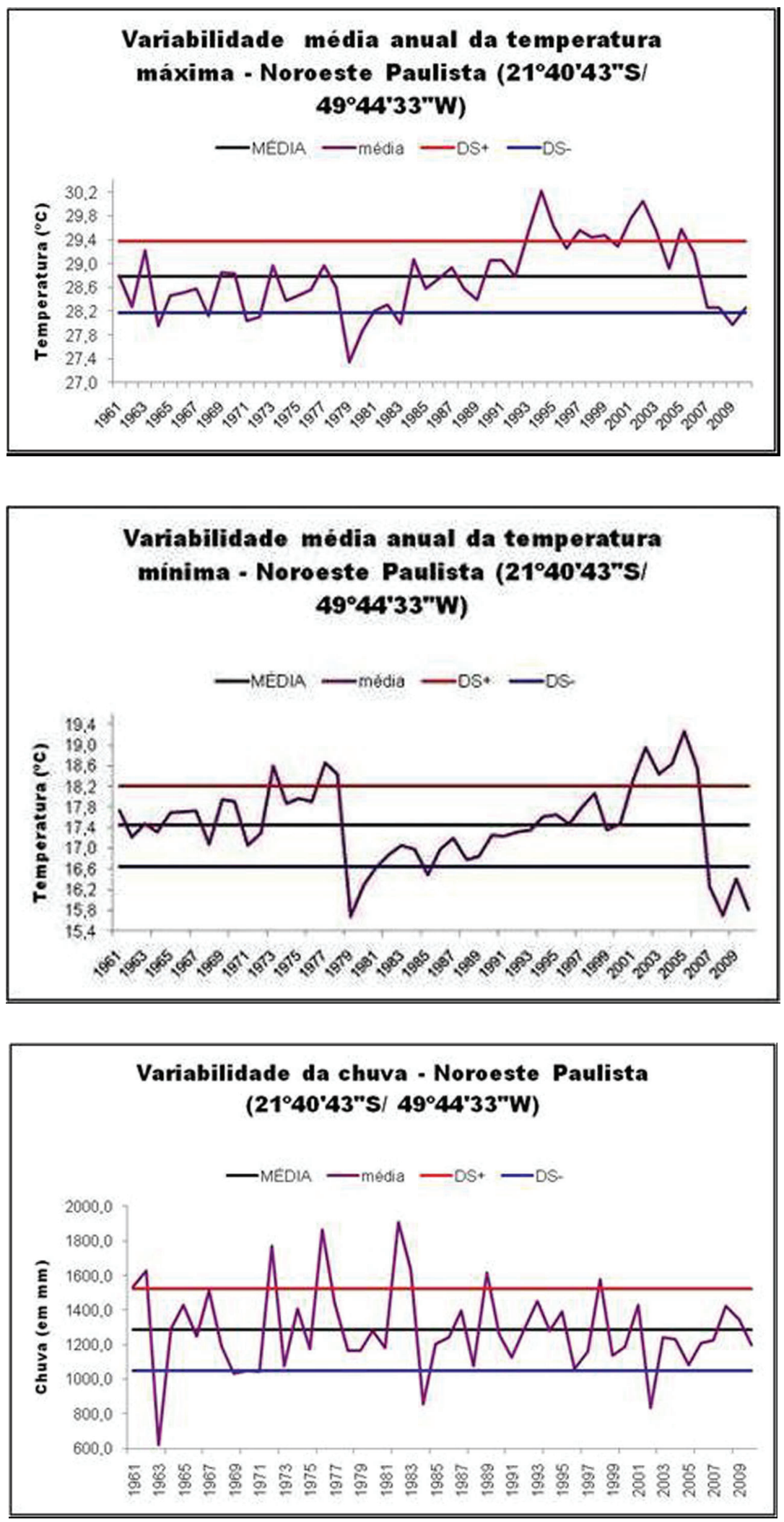

Figura 1 - Gráficos de temperatura e de chuva da região Noroeste Paulista.

Fonte dos dados: Inmet. Disponível em: <http://www.agritempo.gov.br>. Acesso em: 18 abr. 2011. 
Os procedimentos foram realizados em três etapas principais: fundamentação teórica, levantamento de campo e atividades de gabinete (produção cartográfica e escrita).

A fundamentação teórica consistiu na leitura de materiais relacionados à temática qualidade ambiental urbana e subtemas afins, como àqueles relacionados aos indicadores clima urbano, poluição, cobertura vegetal, espaços livres de edificação, drenagem urbana, uso e ocupação do solo.

A saída a campo compreendeu a busca pelos indicadores selecionados, atendendo às demandas de localização e quantificação para a geração das cartas.

O primeiro indicador considerado foi o uso do solo. A classificação de usos é fundamental para compreender a organização espacial da cidade, contribuindo para as ações do planejamento urbano na identificação de problemas. Para isso, foram identificados os seguintes usos: residencial, comercial, serviços, industrial, espaços livres de edificação, lotes vazios e cemitério. Através dessa espacialização, foram verificadas as condições de distribuição de usos na cidade, principalmente a situação de usos inadequados.

Para o tratamento do segundo indicador, a poluição, refinou-se o levantamento da categoria "serviços", de modo que foi possível localizar e quantificar os usos com potencial para causar poluição atmosférica e acústica. Fez-se também um levantamento qualitativo do tráfego, permitindo a espacialização das avenidas mais movimentadas. Essa opção considerou que os veículos automotores liberam diversos poluentes, como monóxido de carbono, hidrocarbonetos, óxidos de nitrogênio e material particulado, "substâncias que, em abundância na atmosfera, prejudicam a qualidade de vida das pessoas, danificam estruturas e peças urbanas e perturbam a flora e a fauna" (HEIBER, 2006, p. 17).

Além das avenidas do entorno da praça central que envolve o principal comércio da cidade, constaram do mapeamento as ruas que dão acesso às principais fontes potenciais de poluição, nas quais se verifica o fluxo não só de veículos leves, mas também de ônibus e caminhões. Essas ruas possuem mais movimento em comparação às demais, e algumas delas fazem a conexão de entrada e saída da cidade.

Outro indicador, a cobertura vegetal arbórea, foi considerada como toda arborização de rua, praças, canteiros, áreas públicas e áreas particulares visíveis em fotografias aéreas na escala 1:5000, obtidas no Google Earth . Para isso, foram utilizados nove recortes da malha urbana na escala que permitiu a visualização das manchas a olho nu (Figura 2). Assim, elaborou-se a carta com a localização de pontos com insuficiência de cobertura vegetal, utilizando os seguintes intervalos: menos de $5 \%$, de $5 \%$ a $30 \%$ e de $31 \%$ a $50 \%$.

Os mesmos recortes da malha urbana foram utilizados para a verificação da densidade de edificação, a partir da observação a olho nu e posterior transposição de informações para o mapeamento, considerando as classificações: densidade alta, densidade média, densidade baixa e sem edificações.

Elaborou-se também a carta com a classificação dos espaços livres de edificação com ausência de vegetação. Considerando que muitos desses espaços não cumprem suas funções estéticas, de lazer e ecológicas (CAVALHEIRO; DEL PICCHIA, 1992, p. 31), essa medida auxiliou na análise das condições de implantação e na verificação daquilo que foi efetivado.

Os dados de temperatura foram utilizados a partir do estudo de Amorim (2006) sobre ilhas de calor em cidades de pequeno porte. Nele, o levantamento ocorrido durante alguns dias da estação de verão (dezembro de 2004) e da estação de inverno (julho de 2005), a partir das 20h, utilizou a metodologia do transecto móvel, coletando-se a temperatura em 51 pontos distribuídos pela cidade, incluindo limites suburbanos e rurais próximos.

Os valores dessas medições foram tabulados no Microsoft EXCEL e espacializados no software Surfer, permitindo a visualização das áreas mais tendentes ao aquecimento e, consequentemente, 
ao desconforto térmico. Com esses fins, foram traçadas as isotermas, tendo como ponto de partida uma data representativa na estação de verão. Por último, foram levantadas informações sobre as enchentes.

Guararapes possui alguns pontos que causam transtornos à população na época das chuvas. Para compreendê-los, houve o mapeamento, baseado em informações cedidas por funcionários da prefeitura, notícias publicadas no jornal Folha da Região e o conhecimento da área. Mesmo sem uma carta da morfologia do terreno, houve a tentativa de verificar as causas da insuficiência do sistema de drenagem urbana, por meio da interpretação dos fatos citados anteriormente.

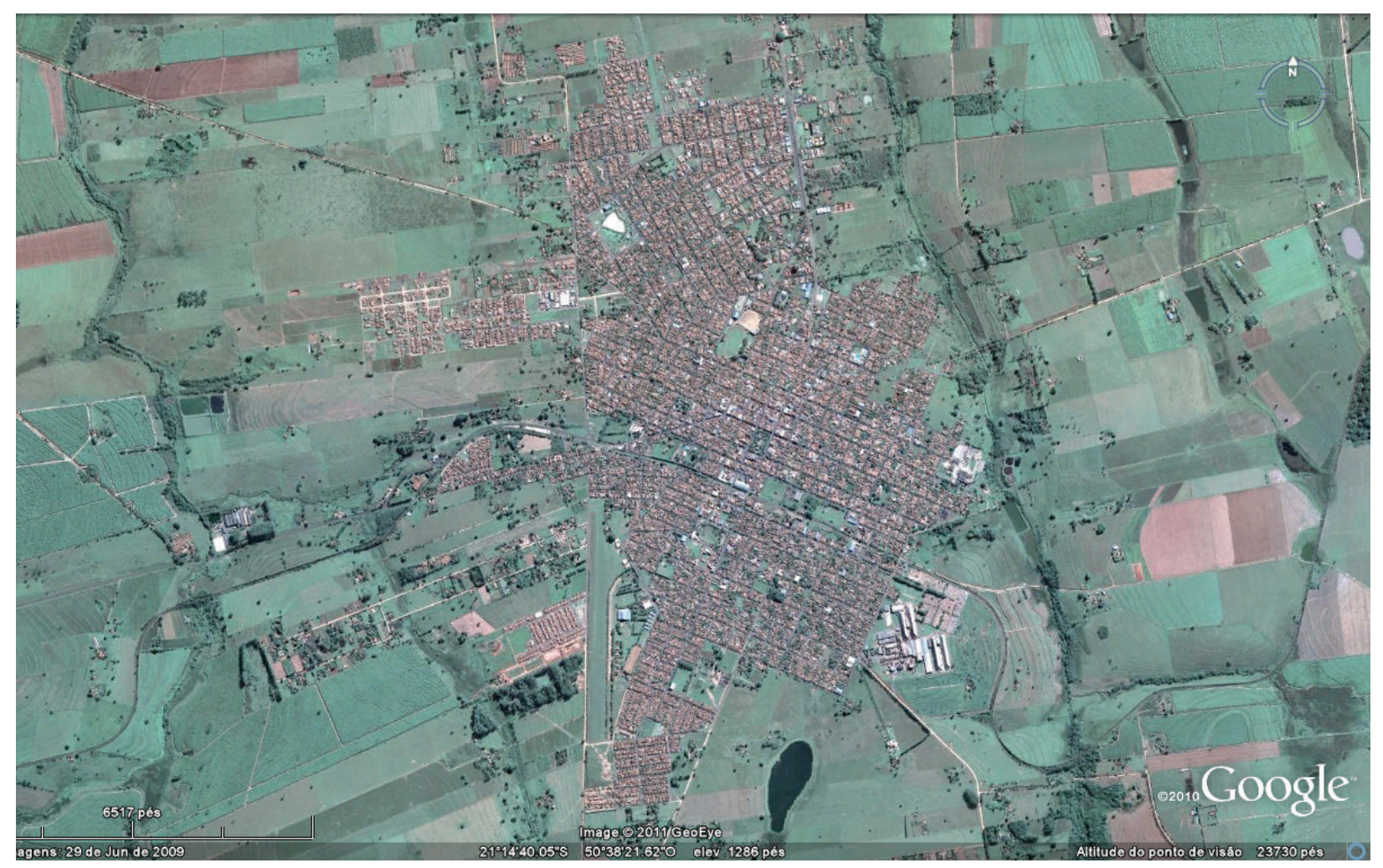

Figura 2 - Malha urbana de Guararapes

Fonte: Google Earth TM mapping service/NASA/Terra Métrics copyright. Acesso em: 13 jun. 2011.

Posterior ao mapeamento dos dados, fez-se um cruzamento do qual foram originadas a carta de cada um dos indicadores e a carta final de qualidade ambiental. Essas cartas receberam nomes com referência negativa, pois se trata de variáveis, cuja ocorrência provoca a queda de qualidade ambiental.

Assim, quanto mais negativos forem os resultados demonstrados pelas cartas dos indicadores, significa que estes ocorreram mais vezes ao mesmo tempo e no mesmo lugar, e pior será a avaliação da qualidade ambiental. Os produtos cartográficos receberam análises individualizadas e, posteriormente, foram integrados à análise das condições ambientais da cidade. Essa metodologia não diferencia qualitativamente nenhum dos indicadores, atribuindo a todos o mesmo peso.

[...] a carta de qualidade ambiental apresenta uma valoração qualitativa, que deve ser analisada de forma relativa, ou seja, a área que apresenta todos os sete atributos tem uma pior qualidade ambiental em relação à que apresenta somente seis atributos, e assim por diante (NUCCI, 2001, p. 190-191).

A tabulação dos dados permitiu a organização dos materiais disponíveis para a sistematização. Para a elaboração das cartas parciais, utilizou-se o programa AutoCAD e o Sistema de Processa- 
mento de Informações Georreferenciadas (SPRING ). A carta síntese de qualidade ambiental urbana de Guararapes foi gerada no programa CorelDRAW .

O uso do geoprocessamento foi necessário para a organização dos dados e posterior mapeamento. Considerando que o material cartográfico indica noções bastante próximas da realidade, a espacialização dos indicadores, por sua vez, abrange as dimensões geográfica e social propostas na análise deste estudo.

\section{ANÁLISE DA QUALIDADE AMBIENTAL URBANA DE GUARARAPES/SP}

\section{Indicador "uso do solo"}

A carta de uso do solo permite interpretar a espacialização dos usos que caracterizam a cidade e, como indicador de qualidade ambiental urbana, refletir sobre o potencial de exploração do solo urbano mediante as condições ambientais que devem ser preservadas. "A utilização do território da cidade está diretamente relacionada com a qualidade do ambiente urbano. Sendo assim, uma carta de uso do solo torna-se importante instrumento para se fazerem inferências" (NUCCI, 2001, p. 131).

Em Guararapes, o uso comercial se concentra na área central da cidade e seu entorno, mas há muitas ocorrências nos demais bairros, por ser uma prática comum a abertura de estabelecimentos voltados ao consumo, atendendo ao aumento da demanda populacional ou ao suprimento de uma atividade ausente. Torna-se mais restrito nos conjuntos habitacionais localizados no setor sul da cidade, apesar de se ter verificado que, em algumas residências, houve o aproveitamento da testada do lote para o arranjo comercial. A leitura do Plano Diretor (Lei municipal 2.347/2006) permite concluir que essa situação é permitida, já que o comércio e o serviço local compreendem todos aqueles que são extensão natural de residências ou compatíveis com estas, mas que não causem incômodos e, se necessário, utilizem equipamentos de isolamento acústico. Nos loteamentos mais recentes, como a Vila Medeiros, o Jardim Europa e o Jardim Satélite, sua proporção também é menor.

$\mathrm{O}$ uso de serviços se concentra mais densamente em toda a área central e seus setores vizinhos e, quando comparado ao uso comercial, é evidente que o perfil desses espaços, além de possuir a diferença de funções, apresenta também a diferença de tamanho, pois se trata de lotes maiores. Isso porque, nessa categoria, foram considerados espaços como os educacionais e médico-hospitalares, que necessitam de maiores extensões.

Também houve menor ocorrência nas áreas de loteamentos recentes e de conjuntos habitacionais. No Jardim Aeroporto, setor sudoeste da cidade, há, por exemplo, somente dois grandes espaços de serviços: o aeroporto municipal, que realiza consertos em aviões de pequeno porte, e um terreno com galpões, quiosques e arena, em que a prefeitura realiza anualmente sua feira agropecuária.

O uso industrial possui baixa ocorrência, pois o município não possui esse tipo de importância, gerando riqueza principalmente pelas atividades rurais. De acordo com a Seção V do Plano Diretor Municipal, há sete áreas que compõem a Zona Industrial, porém, nem todas as localizações foram confirmadas no trabalho de campo, devido à metodologia adotar apenas a observação da frente dos lotes, a partir da fachada das edificações.

A indústria Óleos Menu, localizada ao lado do Jardim Industrial, em área de transição para o limite rural, é a maior. Nas adjacências desse terreno, localizam-se um bairro residencial, o cemitério e a estrada que faz a ligação com o bairro rural Jacutinga.

O Frigorífico da cidade localiza-se às margens de um bairro residencial, o Jardim São Judas Tadeu $2^{\text {a }}$ Seção, embora o afastamento desse tipo de uso não seja suficiente para evitar mau cheiro nos bairros vizinhos e, eventualmente, a presença de insetos. 
O parque industrial no Jardim Europa possui estabelecimentos de pequeno porte e localiza-se ao lado de uma área verde, transformando o espaço em depósito de entulho e de material de construção, como constatado durante as saídas a campo. Embora o uso da palavra "parque" sugira uma grande quantidade de indústrias, estas são em número reduzido e consideradas de baixo impacto ambiental, segundo a legislação local.

O Jardim Europa, construído em um dos novos "braços" que compõem a malha urbana de Guararapes, localiza-se próximo às chácaras que foram delimitadas dentro do perímetro urbano. Por ser relativamente recente, ainda carece de infraestrutura e do loteamento integral das áreas, estando em fase de desenvolvimento. Junto com as outras áreas também mais recentes, configura-se como espaço desprovido do formato tabuleiro de xadrez, modelo espanhol que é o predominante na cidade. As demais ocorrências são áreas no Centro, no Jardim Brasil e no Jardim Estádio, sendo uma indústria de bebidas, uma de grãos e uma fábrica de cadeiras, respectivamente (Figura 3).

\section{Indicador "Poluição"}

Realizar um levantamento direto da poluição é muito custoso, principalmente quando, no município, não há um órgão ambiental que exerça essa função. Nas cidades de pequeno porte, isso é praticamente inviável, por ser considerado dispendioso diante do capital disponível e da demanda de outros problemas considerados de caráter emergencial.

Por isso, utilizou-se a metodologia de Nucci $(1996,2001)$ para que esse indicador pudesse ser analisado durante o trabalho de campo. Todos os tipos de serviços ou atividades considerados potencialmente poluentes foram mapeados. Oficinas mecânicas, retíficas de motores, postos de gasolina, funilarias, ferros-velhos, tapeçarias e transportadoras emitem poluição atmosférica e acústica, por exemplo. São locais de grande concentração de veículos, cujos serviços oferecidos interferem na queda da qualidade ambiental.

Os serviços potencialmente poluentes concentram-se na área central da cidade, onde se verifica a presença de postos de combustíveis, lava a jatos, tapeçarias, autopeças, oficinas mecânicas e funilarias. A Avenida Walter Pagliari, que dá acesso à estrada vicinal, também se destaca com esse tipo de uso. No limite do bairro Área Central com o Jardim São Judas Tadeu $1^{\text {a }}$ Seção, próximo ao pavilhão da polícia, há várias oficinas que prestam serviços a veículos de grande porte. Algumas delas estão próximas de espaços livres de edificação, gerando o contraste de usos incompatíveis, podendo diminuir os possíveis efeitos térmicos desses espaços verdes.

Há também os estacionamentos na Área Central, no entorno do centro comercial, e aqueles mais distantes, utilizados para guardar frotas de ônibus, caminhões e tratores, frequentemente, próximos de uma oficina mecânica ou borracharia. De forma geral, são escassos no Conjunto Habitacional José Garcia, Tenente Rio Branco Antunez, Guararapes III, Loteamento Francisco Antoniolli, Jardim Vila Nova, Vila Medeiros, Jardim Europa, Jardim Santa Maria, Jardim Satélite, Jardim Pioneiro, Jardim Satélite II, Jardim Nossa Senhora Aparecida, Jardim Nossa Senhora da Conceição e Jardim Alvorada. À medida que se afasta do centro da cidade, com exceção da Avenida Walter Pagliari, esses serviços são reduzidos. 


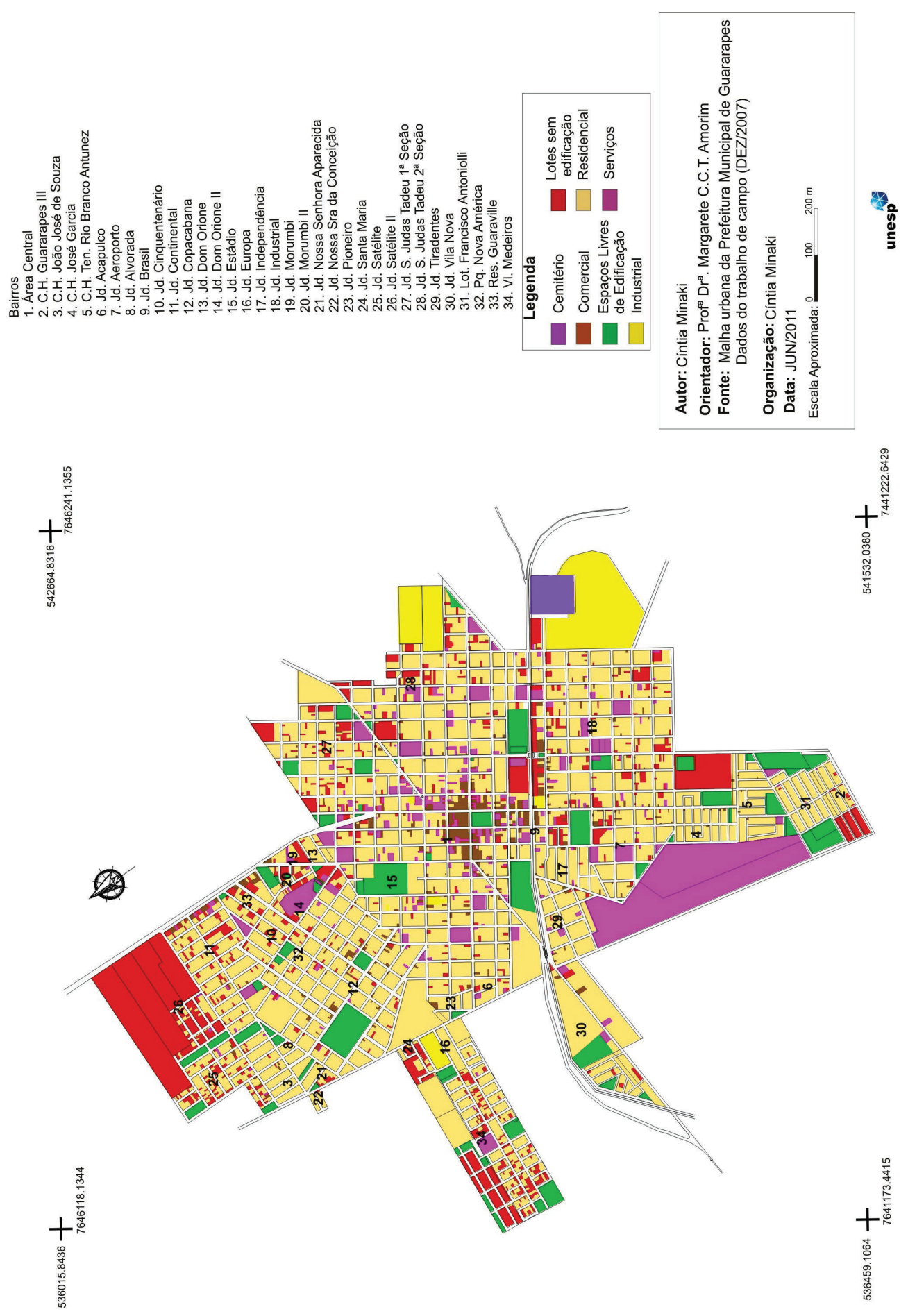

Figura 3 - Guararapes: carta de uso do solo 
As ruas mais movimentadas também constam da carta, pois o constante fluxo de veículos exerce uma forte pressão na queda da qualidade do ar. Avenida Rio Branco, Rua Duque de Caxias, Prudente de Moraes, Campos Sales, Júlio Prestes e Washington Luiz, pela localização e fácil acesso a áreas de importância econômica, foram consideradas no mapeamento.

Essa metodologia permite uma observação mais evidenciada dos serviços potencialmente poluidores, presentes, sobretudo, na Área Central. (Figura 4).

\section{Indicador "enchentes"}

As enchentes são fenômenos naturais que, além de serem provocados por chuvas de magnitude elevada, podem ser decorrentes do transbordamento de cursos d'água, resultantes da urbanização e de mudanças no ciclo hidrológico nas cidades (POMPÊO, 2000, p. 15-16). O adensamento altera o ciclo hidrológico em razão de fatores como a modificação da superfície, a canalização do escoamento, o aumento da poluição por causa do ar contaminado, das superfícies urbanas e do material sólido utilizado pela população (TUCCI, 2003, p. 36). O ciclo hidrológico, um subsistema do sistema urbano, é mais um integrante que passa a atuar em desequilíbrio. Como exemplo, o aumento da vazão torna-se comum graças ao escoamento canalizado e à diminuição da evapotranspiração.

Esse indicador, quando não abordado pelo planejamento urbano, pode se tornar muito dispendioso não só em termos financeiros. Nas cidades em que não há planejamento da drenagem urbana, tornam-se comuns problemas como a inundação. Isso se agrava pelo fato de que a população de classe social baixa é quem mais sofre as consequências do mau ordenamento do solo urbano.

Guararapes possui situações de risco em alguns pontos, que devido à localização, em altitudes inferiores, necessitaram da criação de lagoas de recepção para melhoria do seu sistema de drenagem. Um exemplo foi o aproveitamento de uma área úmida, a 388 m [s.n.m.], a partir de um projeto de recuperação concluído em 1994.

A localização em fundo de vale trouxe a essa área problemas de inundações, minimizados com a construção de um reservatório de água pluvial. Passou-se a captar as águas pluviais, reduzindo os problemas que afetavam a população do seu entorno e desvalorizavam o local, popularmente referido pelo seu mau cheiro e pela presença de anfíbios que adentravam as casas dos moradores. Apesar da construção de uma praça pública e da instalação de equipamentos voltados à ginástica terem aumentado seu uso, ainda se nota a insuficiência na manutenção do sistema pluvial quando ocorrem episódios extremos de precipitação, tratando-se, portanto, de uma área de risco.

Outra área com potencial de inundação localiza-se no Jardim Copacabana. O ponto em questão também foi transformado em área verde (Centro de Lazer dos Trabalhadores "Laurentino F. da Silva"). A 378 m [s.n.m.], a antiga "Lagoa" transformou-se em um espaço de lazer. No centro da área, há dois reservatórios, sendo que o menor é a área de captação das águas pluviais, onde cinco tubulações captam as águas do entorno da área, e a outra é responsável pela drenagem da área vizinha, constituindo-se como uma lagoa artificial. Além dessa tentativa de diminuir o transbordamento comum na estação chuvosa, pedras foram depositadas no reservatório de captação para a sua melhor retenção.

As obras realizadas nessas duas áreas contribuíram para a diminuição dos problemas, mas se transformaram muito mais em um resgate cultural do uso de ambos os locais do que um instrumento de infraestrutura. Ressalta-se, ainda, o distanciamento da população com os problemas da cidade, que fica evidente nesses casos, já que a importância é dada muito mais à inauguração de uma praça ou área verde do que à minimização de um problema ambiental urbano. Logo, nem toda a população reconhece a realidade e as necessidades das áreas que frequenta e habita. Consequentemente, deixa de dar suporte para a manutenção de um sistema urbano mais estável. 


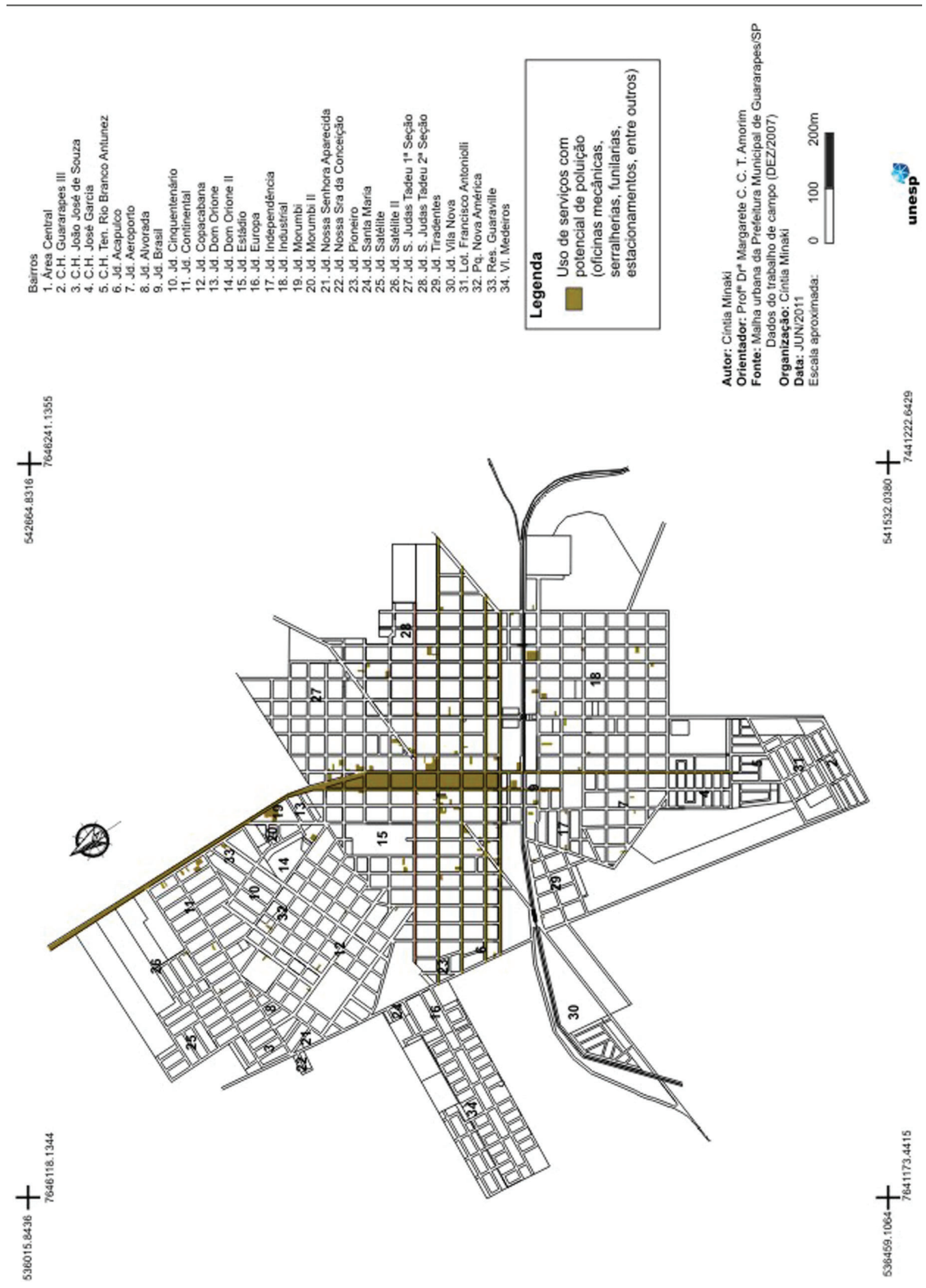

Figura 4 - Guararapes: carta das áreas com potencial de poluição 
Uma terceira área com problemas de inundação localiza-se no Jardim Industrial. A lagoa do Bregalante, como é conhecida, é um fundo de várzea que também apresenta problemas de captação de águas pluviais na estação chuvosa. A água escoada nessa região envolve todas as quadras a partir do Tiro de Guerra. Diferentemente das áreas anteriores, trata-se de um reservatório isolado por cerca e muito próximo da área rural, sendo seu acesso dificultado por não ser uma área de lazer.

Outra área de risco localiza-se no bairro Jardim São Judas Tadeu $1^{\text {a }}$ Seção, no qual foram construídas, em 2006, obras para conter as inundações que atingiam o interior de algumas residências. Fez-se um projeto para o escoamento de águas pluviais das ruas Brasil, Vitório Paladino e dos Fundadores até o Córrego Frutal. Nas situações em que o volume de precipitação é muito elevado, os habitantes do seu entorno podem sofrer as consequências dessa ocupação de risco. Assim, chega-se a uma conclusão bastante comum em várias cidades brasileiras: a de que as obras de contenção de enchentes são, muitas vezes, realizadas considerando-se um padrão médio de chuva, quando o planejamento deve se fundamentar nas possibilidades de ocorrerem situações extremas, que são aquelas que causarão maiores danos.

A espacialização das principais áreas com insuficiência de drenagem urbana encontra-se na figura a seguir, cuja visualização demonstra a existência de problemas nas quatro extremidades da malha urbana (Figura 5).

\section{Indicador "conforto térmico"}

Os ambientes construídos, dependendo das características internas e de sua arquitetura, podem oferecer desconforto, seja pela temperatura elevada ou pela falta de ventilação. As propriedades dos materiais de construção urbana possuem maior potencial de absorção de energia, convertendo-a em calor. Logo, o calor antropogênico gerado nas cidades advém desses materiais e de fatores como o excesso de concentração humana e atividades que liberam mais energia. A formação de climas urbanos acaba sendo uma ocorrência comum diante da urbanização acelerada que caracteriza o país.

Essa formação também comprova a diferença entre a composição do balanço de energia urbano e rural. Considerando-se as diferenças estruturais em ambos os ambientes, o urbano tende a reter maior quantidade de energia por mais tempo, o que explica a variação dos padrões nessa atmosfera. E, com a construção das cidades, o primeiro elemento a ser retirado é a vegetação, ocorrendo alterações na quantidade de armazenamento de água e no processo de evapotranspiração, influenciando na diminuição da umidade nos ambientes urbanos.

Para a elaboração da carta de conforto térmico, foram utilizados os dados de Amorim (2006), que desenvolveu um projeto sobre ilhas de calor noturnas, coletando dados de temperatura em Guararapes através da metodologia do transecto móvel em dez dias da estação chuvosa (18 a 28 de dezembro de 2004). O conforto térmico deve ser produzido como um elemento de qualidade ambiental, pois, considerando a configuração dos grandes centros urbanos, dificilmente seráuma variável de ocorrência natural. Nesta pesquisa, considerou-se em situação de conforto as áreas que apresentaram as menores temperaturas variando até, aproximadamente, $26^{\circ} \mathrm{C}$.

Foram 51 pontos dentro da malha urbana, onde se realizou um percurso de automóvel com a velocidade máxima de $30 \mathrm{~km} / \mathrm{h}$. Uma haste com um sensor acoplado à sua extremidade foi exposta pela janela do automóvel, ficando ao ar livre. Na passagem por cada um dos pontos, anotou-se a temperatura indicada pelo sensor no final da haste e registrada no termômetro digital nas mãos do pesquisador. No final do trajeto, obteve-se o total de temperaturas equivalente ao total de pontos escolhidos que abrangeram a camada intraurbana e áreas rurais próximas. 


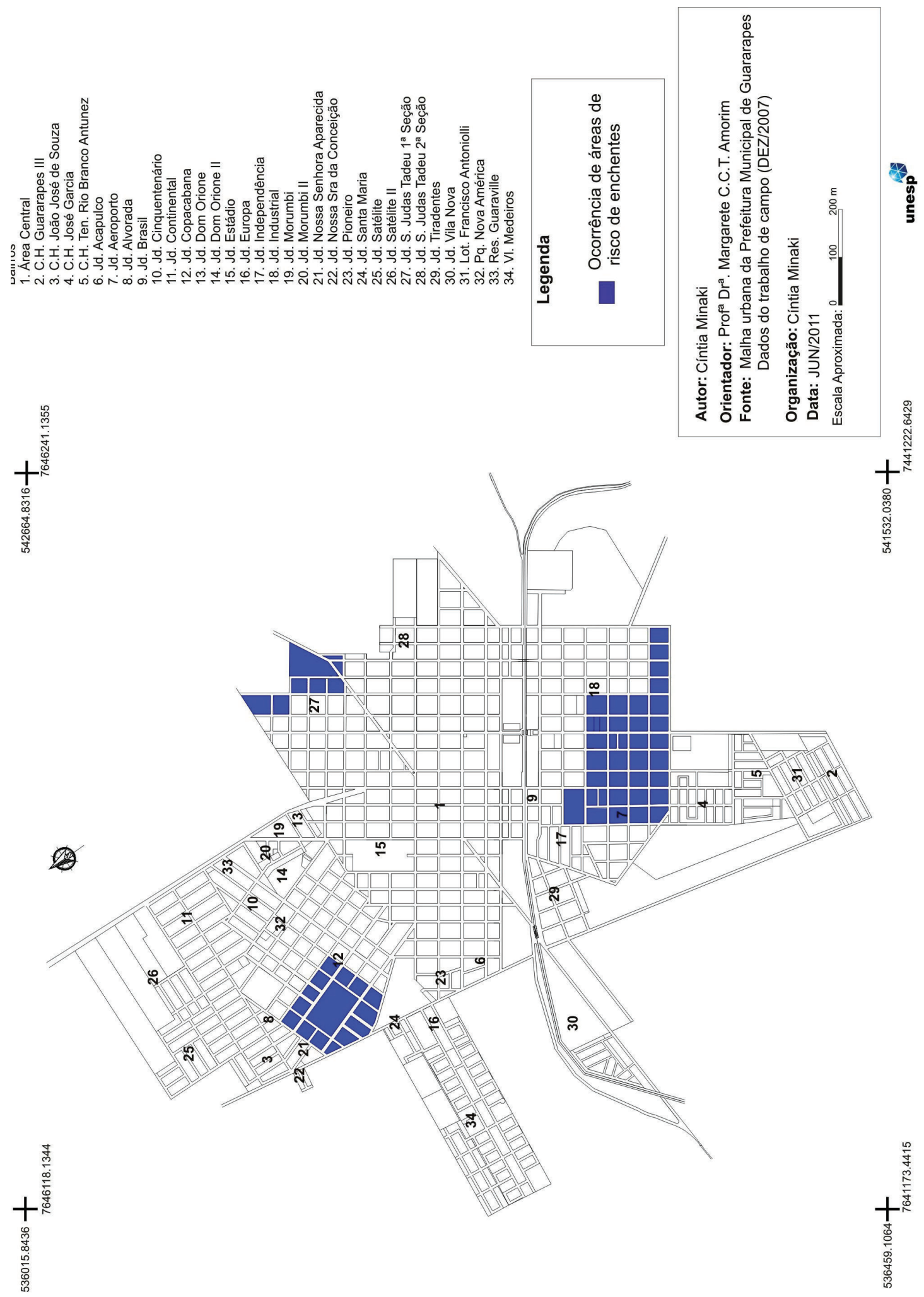

Figura 5 - Guararapes: carta de risco de enchentes 
Acredita-se que a densidade de construção seja um fator determinante das características térmicas observadas, principalmente no entorno da praça na Área Central. Embora haja mais áreas com cobertura vegetal nesse bairro, há maior ocupação e concentração de atividades poluentes. A análise do dia 28 de dezembro de 2004 , em que se obteve diferença térmica de $4,3^{\circ} \mathrm{C}$, permitiu verificar maior aquecimento na área central e em alguns bairros do setor norte da cidade, bastante desprovido de cobertura vegetal arbórea. Os resultados encontram-se na Figura 6.

Indicador "espaços livres de edificação"

Foram considerados espaços livres de edificação os espaços urbanos ao ar livre destinados a usos como caminhadas, descanso, passeio, prática de esportes, recreação e entretenimento em horas de ócio, podendo ser privados ou públicos, mas potencialmente coletivos (CAVALHEIRO et al., 1999). Por meio do trabalho de campo, foram constatados, em Guararapes, 61 espaços livres de edificação, dos quais houve a classificação em áreas verdes, praças públicas, sistemas de lazer e área institucional.

Houve o levantamento de 27 áreas verdes, ou seja, espaços livres com predominância de vegetação (CAVALHEIRO et al., 1999). A presença dessas áreas, além de contribuir para a melhoria da paisagem, pode amenizar o clima urbano, favorecendo a qualidade ambiental urbana. A permeabilidade do solo e a cobertura vegetal predominante são as características indispensáveis para a sua classificação. A espacialização destas se encontra concentrada mais ao norte, sul e oeste da cidade, sendo que, na parte central e áreas adjacentes, estão presentes as praças públicas, aqui diferenciadas das áreas verdes pela presença de equipamentos urbanos.

Verificou-se, ainda, a existência de 13 praças públicas, localizadas, principalmente, na porção central da cidade. A maior parte delas se constituiu a partir de terrenos pequenos, em rotatórias ou nos extremos de quadras com uso residencial e misto.

Os sistemas de lazer totalizaram 12 espaços, sendo consideradas todas as áreas que possuíam um conjunto de equipamentos com a função única de atender ao lazer coletivo. Por isso, alguns espaços nomeados como praças foram incluídos nesta classificação pela sua funcionalidade. A Vila Medeiros se destacou pela presença de sistemas de lazer que consistem em terrenos vazios.

As áreas institucionais, reservadas para finalidade pública, tais como educação, cultural, saúde e administração, representaram seis espaços na cidade, em áreas afastadas do centro, principalmente nos setores sul e noroeste. Desse total, quatro estão vazias e sem ocupação, e duas delas possuem prédios municipais construídos. Além disso, houve o mapeamento de três clubes particulares.

Ficou evidenciado que a maior parte das áreas verdes, praças e sistemas de lazer possuem cobertura vegetal predominante, principalmente a rasteira. Nas áreas institucionais, não se verificou o predomínio de cobertura vegetal. Além disso, dois sistemas de lazer na Vila Medeiros ainda não foram implantados. A carta permite concluir também que, nas áreas centrais, não foram verificados espaços descaracterizados em termos de vegetação e que somente em dois pontos da malha registrou-se esse tipo de ocorrência. Ressalta-se, ainda, a presença de espaços livres, principalmente áreas verdes, nas quadras à borda da malha urbana, demonstrando que estas podem ter sido criadas a partir das sobras de terreno dos loteamentos, para fins de legalização (Figura 7).

Indicador "cobertura vegetal arbórea"

A cobertura vegetal nem sempre é valorizada nos projetos urbanos sendo, muitas vezes, reduzida à finalidade estética. Assim, os jardins, as praças e o verde de acompanhamento viário recebem uma importância mais paisagística do que relacionada ao conforto ambiental. Conclui-se, portanto, que a maioria dos espaços urbanos é desprovida de cobertura vegetal densa, satisfatória, cujos benefícios vão além do embelezamento da paisagem. 


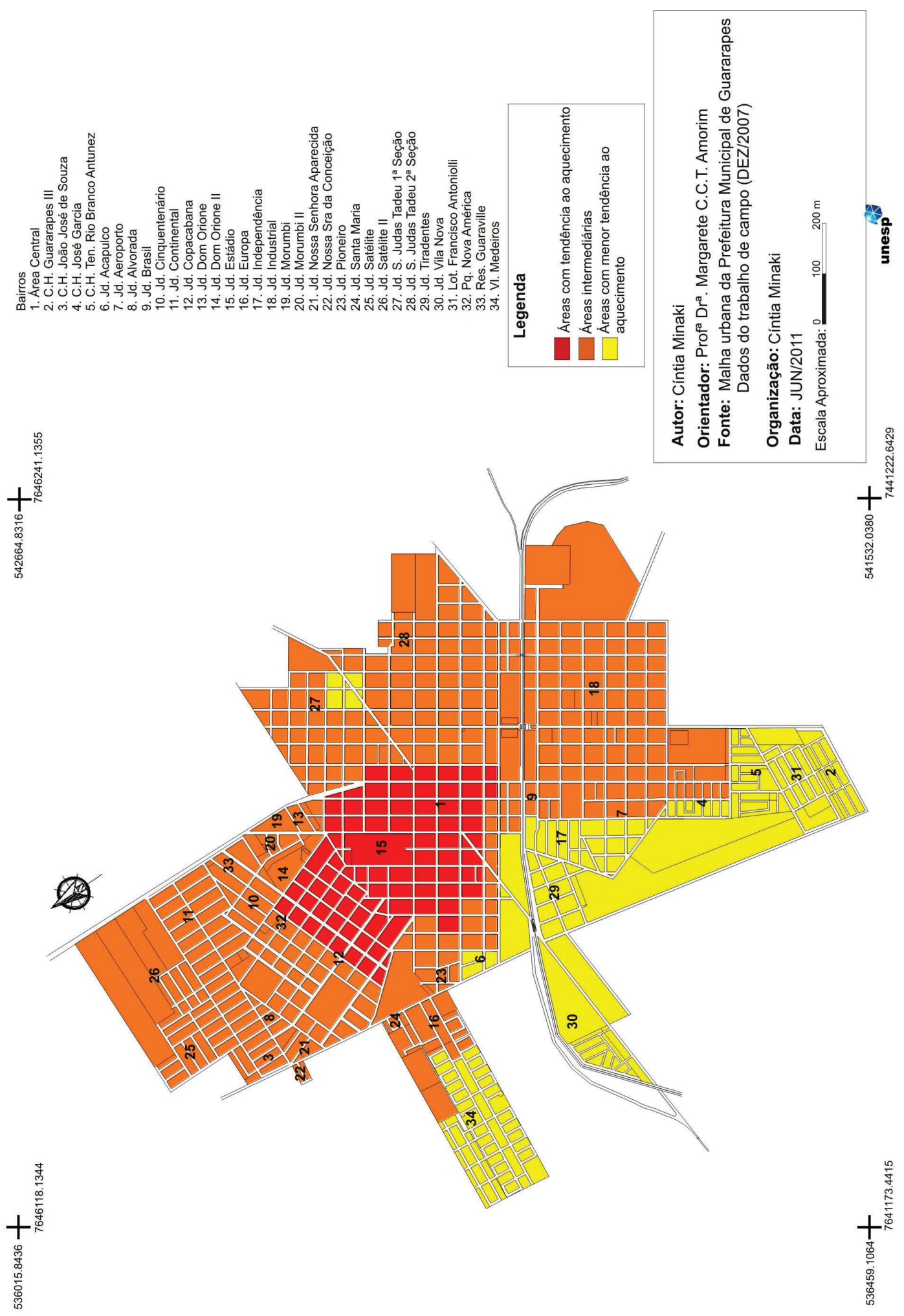

Figura 6 - Guararapes: carta das áreas com tendência ao aquecimento 
Segundo Nucci e Cavalheiro (1999), a cobertura vegetal pode ser interpretada pelo verde projetado em cartas planimétricas, identificada por fotografias aéreas, sem estereoscopia. Dessa forma, foram consideradas como cobertura vegetal as praças, os jardins, os canteiros de acompanhamento viário e a vegetação localizada em áreas públicas e particulares. As manchas foram observadas a olho nu nas fotografias aéreas extraídas do Google Earth, na escala 1:5000.

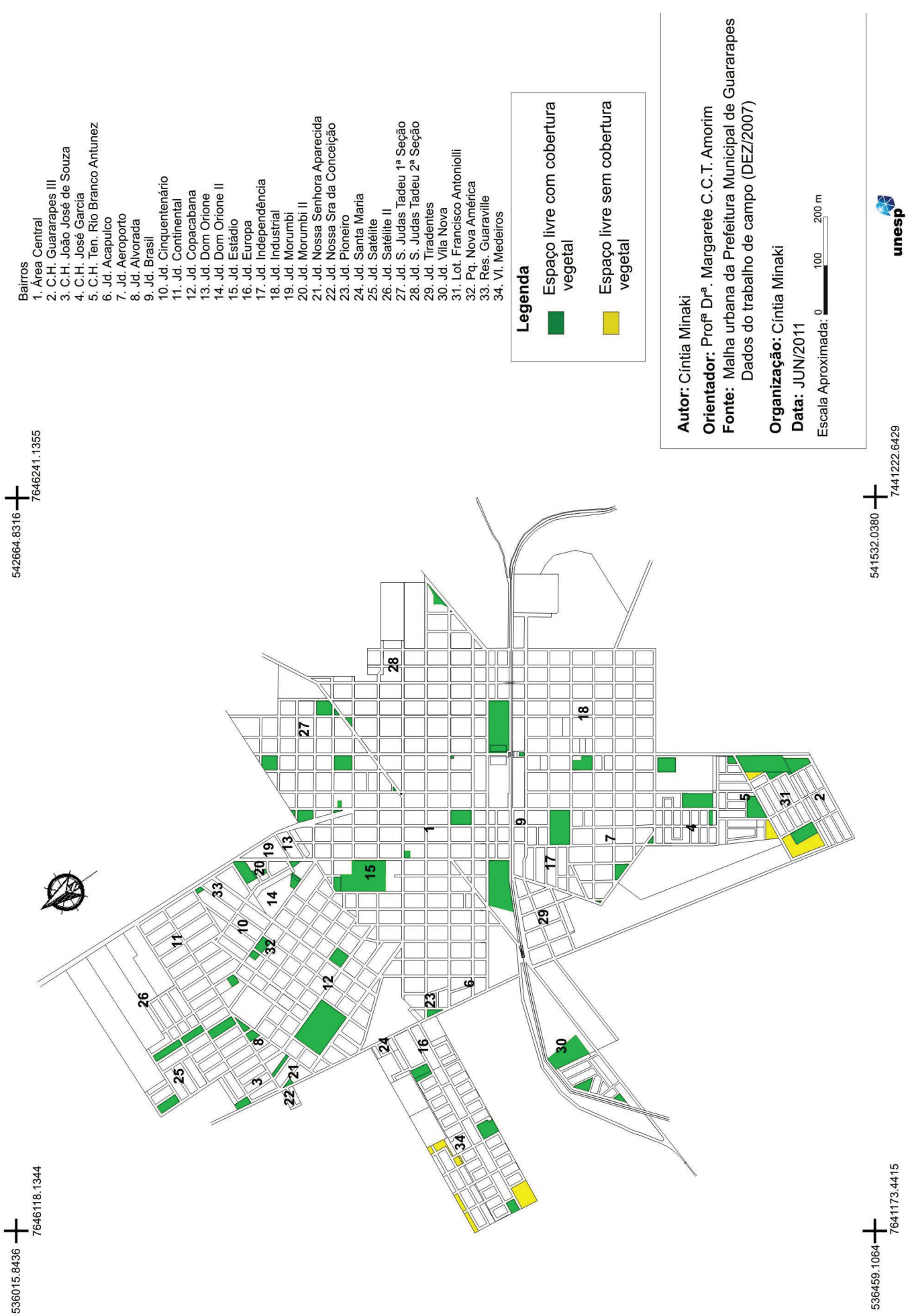

Figura 7 - Guararapes: cobertura vegetal nos espaços livres de edificação 
É sabido que a vegetação favorece o solo, a hidrografia, o clima urbano e influencia diretamente na qualidade ambiental das populações. Além disso, pode atuar na mudança de direção ou quebra da velocidade dos ventos, podendo ser este um aspecto negativo, uma vez que poderá desfavorecer áreas que sofrem com o calor excessivo no período diurno, mas, por outro lado, diminui o stress ao frio noturno em algumas áreas.

Há vários índices de cobertura vegetal, os quais variam em termos de intervalos e porcentagem. Oke (1973 apud LOMBARDO, 1985) calcula que o recomendável estaria na faixa dos 30\%, dessa forma proporcionando o balanço térmico favorável às áreas urbanas.

Com o recorte da malha urbana, para fins de detalhamento, foram utilizadas nove fotografias aéreas. A partir da identificação de cobertura vegetal nas quadras, elaborou-se a Carta de Cobertura Vegetal Arbórea (Figura 8).

A espacialização demonstrou que há problemas principalmente no Jardim Satélite e na Vila Medeiros, ambos loteamentos recentes onde, durante o levantamento de campo, verificou-se ausência de infraestrutura. Além disso, esses loteamentos localizam-se nas bordas da malha urbana: o primeiro, no setor norte da cidade, e o segundo, a noroeste.

\section{Indicador "densidade de edificações"}

Entende-se por densidade de edificações a quantidade de construções em uma determinada área. Com o avanço da urbanização, uma de suas particularidades é a alta concentração de pessoas e de ambientes construídos. Estes são entendidos como uma artificialização do meio, cuja configuração espacial e características podem acarretar prejuízos à qualidade ambiental.

Essa variável foi constatada a partir de fotografias aéreas, nas quais todas as dimensões internas dos lotes puderam ser visualizadas, facilitando a interpretação. A partir disso, foram considerados padrões de observação a olho nu para caracterizar a densidade como alta, média, baixa ou sem edificação.

Os padrões de maior ocorrência em Guararapes foram o alto e o médio. Em algumas áreas, verificou-se baixa densidade e, nos espaços livres de edificação, não se verificou nenhum padrão de densidade, caracterizando outro componente da legenda: as áreas sem edificações.

O setor central, o setor entre o norte-noroeste, além do setor sul, são aqueles que apresentam as maiores densidades de edificação. Bairros como Área Central, Jardim Vila Nova, Jardim Independência, São Judas Tadeu $1^{\mathrm{a}}$ e $2^{\mathrm{a}}$ Seção e Jardim Copacabana se destacam. Os conjuntos habitacionais José Garcia, Tenente Rio Branco Antunez, Guararapes III e o Loteamento Francisco Antoniolli são outros exemplos de áreas densamente edificadas, só que mais distantes da porção central.

O Jardim Satélite I e II, e a Vila Medeiros, áreas de implantação mais recentes, possuem variação entre densidade média e baixa. Há duas extensas áreas nesses locais ainda com projetos de edificação, portanto, vazias. Outra característica que pode ser facilmente constatada é a existência de poucas, mas grandes áreas com baixa densidade de edificações. Trata-se, em alguns casos, de praças, áreas verdes ou sistemas de lazer, recintos, destinados às festas da cidade, e chácaras localizadas nos limites urbanos. 


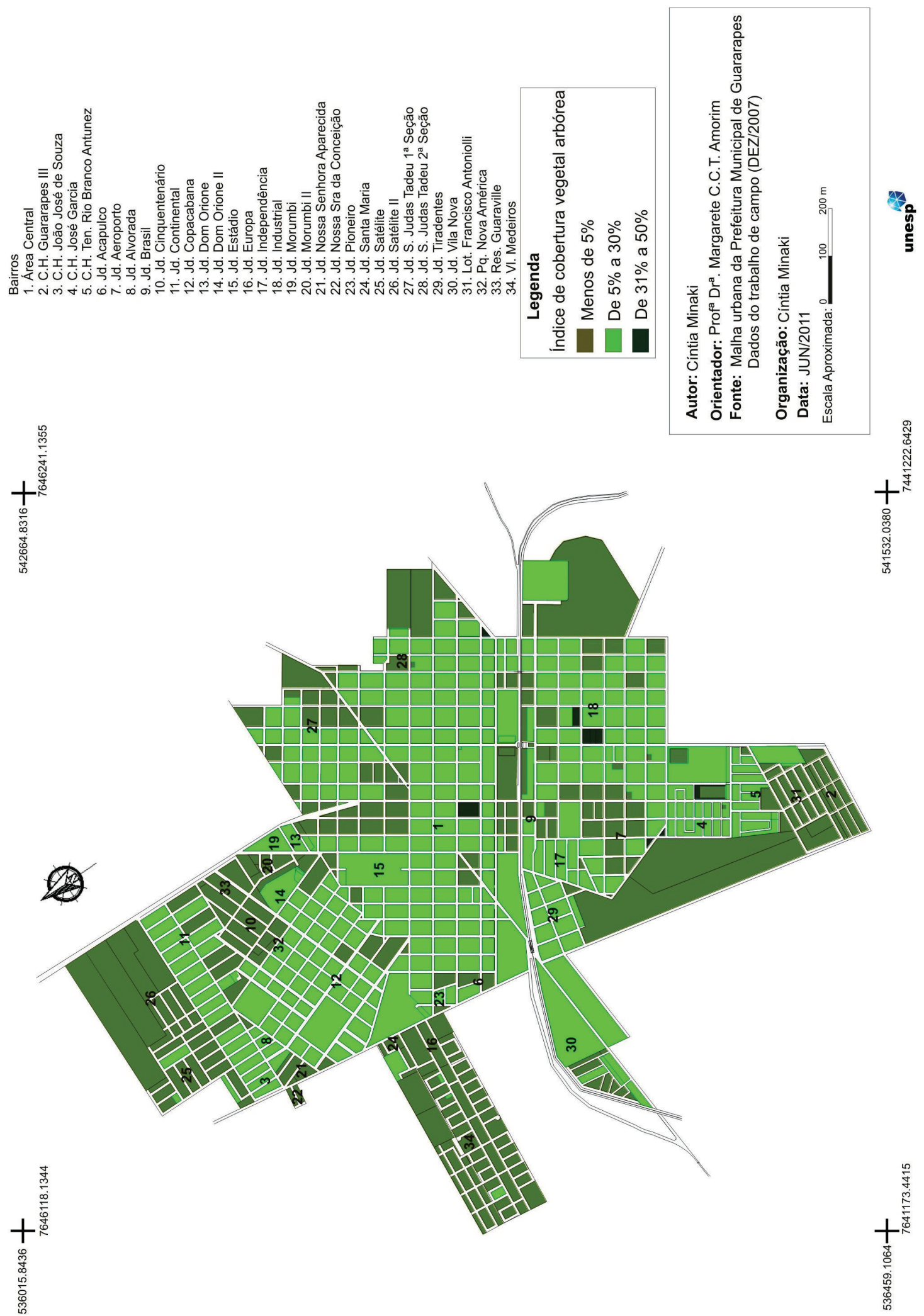

Figura 8-Guararapes: carta de cobertura vegetal arbórea 
De forma geral, as laterais do contorno da malha urbana não se caracterizam por altas densidades, como pode ser observado na Figura 9.

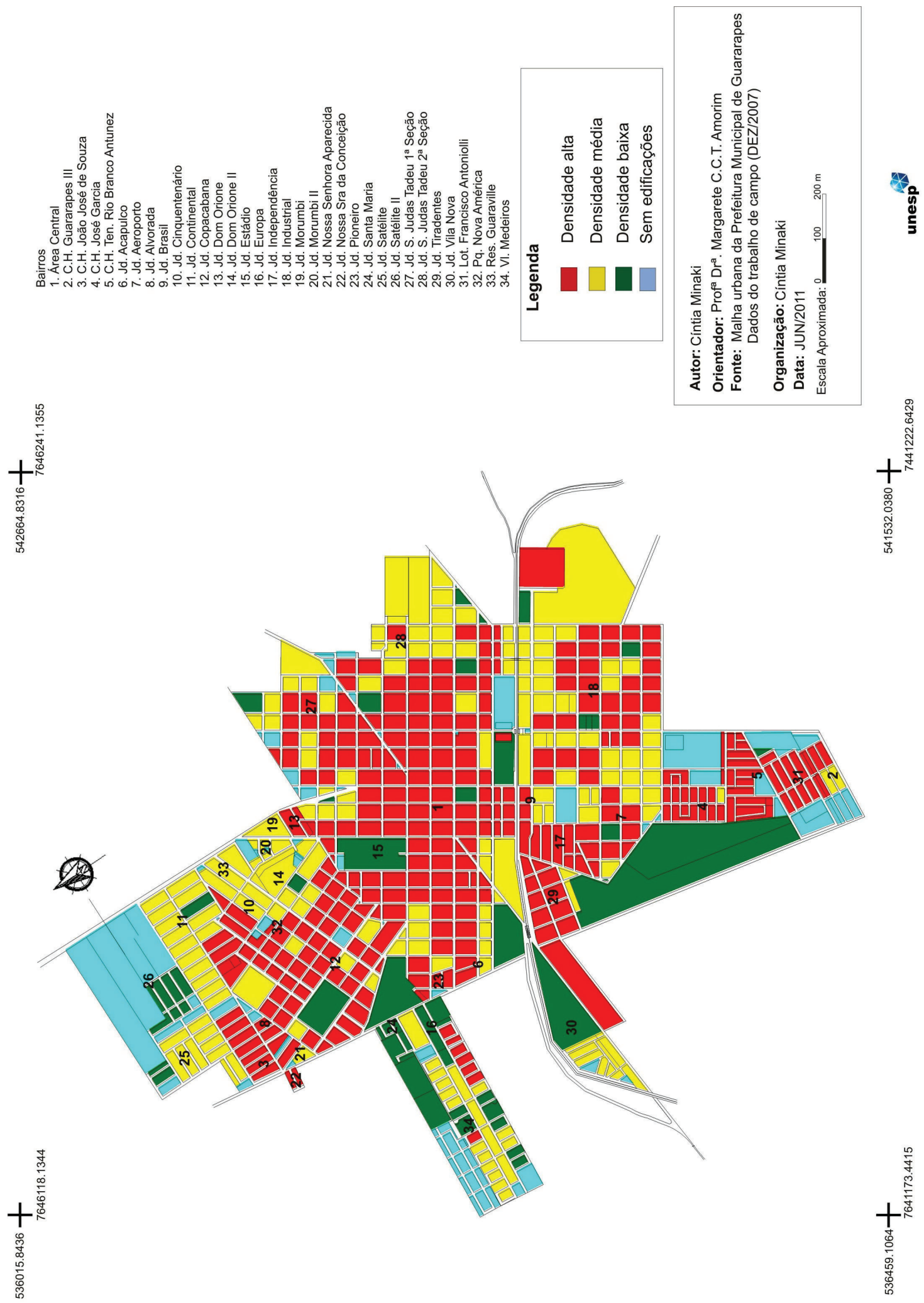

Figura 9 - Guararapes: carta de densidade de edificações 


\section{CARTA DE QUALIDADE AMBIENTAL URBANA DE GUARARAPES/SP}

A partir do mapeamento de todos os indicadores - uso do solo, enchentes, conforto térmico, poluição, cobertura vegetal arbórea, espaços livres de edificação e densidade de edificações -, houve a sobreposição das respectivas malhas para a geração da carta síntese. De acordo com a carta de qualidade ambiental urbana de Guararapes, houve a ocorrência de até quatro indicadores negativos em uma mesma área. As conclusões a seguir foram extraídas pela observação da Figura 10 e pelos dados do trabalho de campo.

Nos bairros Área Central, Jardim Aeroporto, Jardim Copacabana e Jardim Estádio, verificou-se a ocorrência de até quatro indicadores negativos, caracterizando o grupo com a maior tendência à queda da qualidade ambiental urbana, de acordo com os indicadores selecionados. Os três primeiros bairros possuem uma localização mais próxima, no setor norte da cidade.

No Conjunto Habitacional João José de Souza, Jardim Industrial, Jardim Morumbi II, Jardim São Judas Tadeu $1^{\text {a }}$ Seção, Jardim São Judas Tadeu $2^{\text {a }}$ Seção, Parque Nova América e Residencial Guaraville, ocorreram até três indicadores negativos. A sobreposição de dois indicadores negativos foi verificada em 14 bairros da cidade, enquanto a presença de um indicador negativo ocorreu em nove bairros.

Embora alguns bairros tenham apresentado pela carta qualidade ambiental reduzida, as situações devem ser ponderadas, devido ao predomínio de quadras com menor sobreposição dos indicadores. A partir disso, conclui-se que a Área Central foi o bairro onde ocorreu a maior quantidade de indicadores negativos sobrepostos (4), enquanto nos demais bairros, apenas uma das quadras atingiu essa mesma condição. Houve o predomínio de até dois indicadores sobrepostos por quadras.

A maior concentração de pessoas e de atividades econômicas, assim como as características da estrutura urbana, gera um maior potencial de degradação do espaço urbano em Guararapes. A presença de áreas verdes e de espaços livres de edificação que não cumprem sua função de amenização da temperatura ou não são suficientes é um problema que deve ser revertido pela administração local.

\section{CONSIDERAÇÕES FINAIS}

Conclui-se que os estudos de qualidade ambiental urbana, a partir de indicadores objetivos, precisam ser ampliados mesmo em cidades de pequeno porte, cujas características podem indicar um potencial de ocupação que ultrapassa os limites da dinâmica natural do habitat. Enquanto a autonomia da temática não for alcançada, a abordagem ficará reduzida a estudos individualizados dos indicadores, não evidenciando que a qualidade ambiental funciona como um subsistema dentro dos sistemas urbanos já afetados pelas consequências do modo de vida em sociedade.

Observou-se, portanto, o condicionamento de situações desfavoráveis à qualidade ambiental, devido à ocupação desordenada e à reduzida atuação do planejamento urbano. Associadas ao problema, questões como a limitada conscientização ambiental da população e o descaso com os espaços livres de edificação como potenciais de amenização térmica puderam ser verificadas do ponto de vista da observação de geoindicadores do espaço urbano de Guararapes.

Pela carta de qualidade ambiental, ficou evidente que as áreas densamente edificadas, do centro da cidade e arredores, são as que possuem os maiores problemas com relação à queda de qualidade, segundo os indicadores estudados. Os bairros que surgiram no entorno da cidade são os que ainda podem ofertar melhor qualidade ambiental, embora tenha se verificado a insuficiência de infraestrutura nesses locais. Trata-se, portanto, de uma condição que, para ser implementada, depende da efetivação de políticas públicas; caso contrário, tende-se a ofertar espaços que podem ser ocupados desordenadamente e originar os mesmos problemas verificados nas áreas mais antigas. 

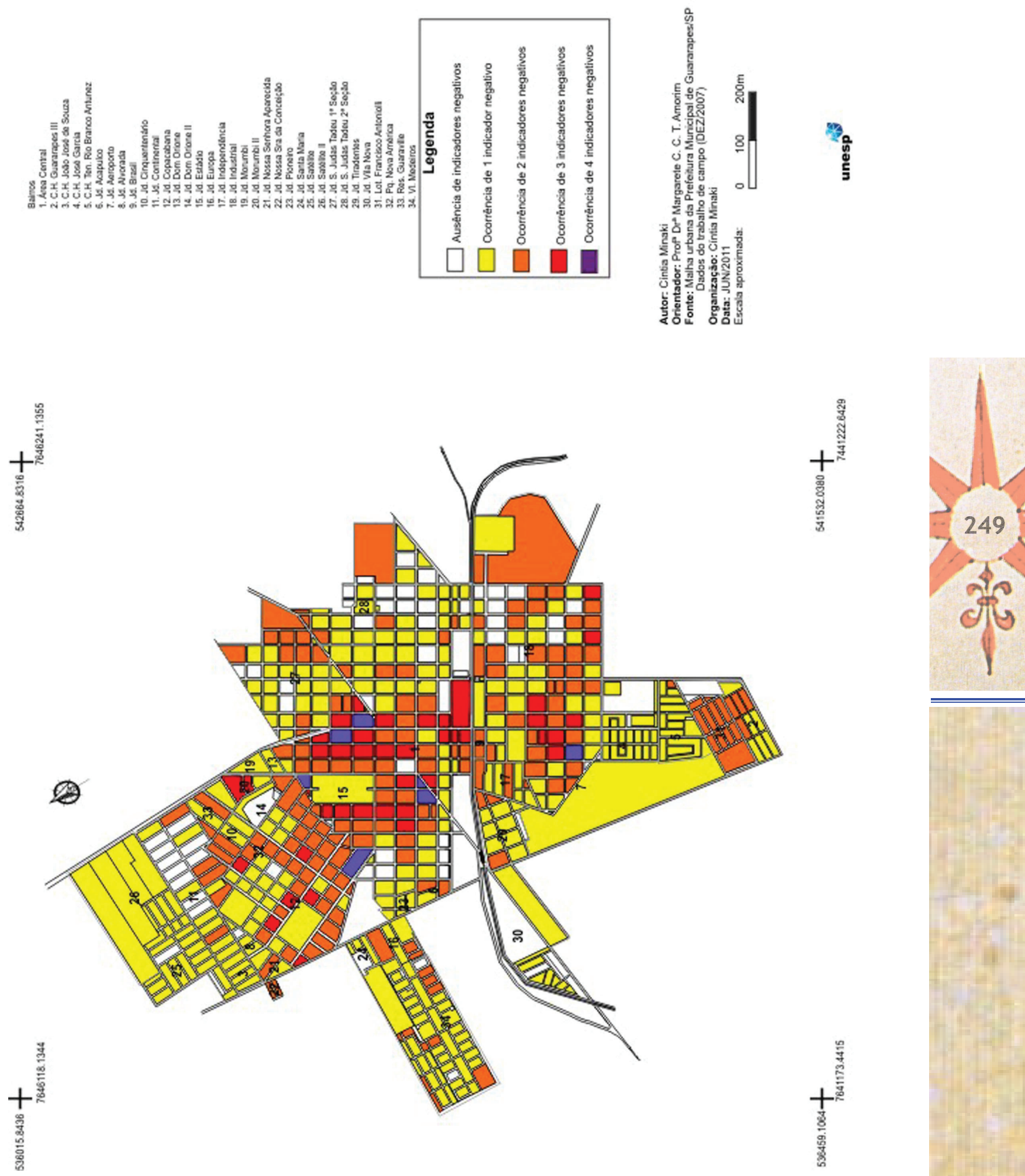

Figura 11 - Guararapes: carta de qualidade ambiental urbana 
A concentração de atividades comerciais e de serviços, além da cultura característica de se habitar as áreas centrais em cidades pequenas, uma vez que não possuem o mesmo status que os "centros velhos" das grandes capitais brasileiras, faz com que estes locais sejam mais procurados para habitação, resultando na alta densidade de edificações. Se, por um lado, há vantagens, como a melhor manutenção da infraestrutura e dos espaços como as praças públicas, por outro lado, a ocupação acaba gerando mais problemas nessa área, ao misturar o uso residencial com usos incompatíveis.

Diante do exposto, alguns aspectos podem ser considerados para a melhoria da gestão ambiental da cidade:

- Planejar e fiscalizar o uso do solo;

- Seguir as normas do Plano Diretor e respeitar o zoneamento urbano;

- Dar legitimidade ao projeto de expansão urbana da cidade;

- Realizar campanhas de conscientização ambiental para aproximar a população com a temática qualidade ambiental e fazer o registro de suas opiniões para um melhor projeto urbanístico da cidade;

- Promover a reciclagem para incentivar a população a não entupir as bocas de lobo com resíduos sólidos, que normalmente são jogados e acabam prejudicando o sistema de drenagem urbana;

- Impulsionar o uso dos espaços livres de edificação com oferta de serviços em seus limites, propagando seu bom uso e sua limpeza;

- Incorporar a população à rotina das assembleias realizadas pela seção legislativa do município;

- Atualizar os serviços de levantamento de dados geográficos do município;

- Estabelecer índices de vegetação para os bairros, para que, desde o projeto de implantação, haja a preocupação em aumentar os espaços com cobertura vegetal;

- Criar políticas para diminuir a impermeabilização do solo urbano, como as calçadas verdes, por exemplo.

São inúmeras as formas de se reduzir os impactos ambientais, considerando que, em uma cidade pequena, os problemas ainda são potencialmente menores. Promover campanhas e definir atitudes são ações complexas, mas cabe ao poder público iniciá-las para o bem-estar dos cidadãos. Aos poucos, pode-se configurar um ambiente urbano mais justo e menos vulnerável à queda da qualidade ambiental.

\section{REFERÊNCIA BIBLIOGRÁFICA}

AMORIM, Margarete Cristiane de Costa Trindade. Ilhas de calor urbanas em episódios de verão e de inverno. Anais do VII Simpósio Brasileiro de Climatologia Geográfica - 20 a 25 ago. 2006. Universidade Federal do Mato Grosso, Rondonópolis. p. 73.

CAVALHEIRO, Felisberto; DEL PICCHIA, Paulo Celso Dornelles. Áreas verdes: conceitos, objetivos e diretrizes para o planejamento. In: Anais do $\mathbf{1}^{\circ}$ Congresso Brasileiro sobre Arborização Urbana e $4^{\circ}$ Encontro Nacional sobre Arborização Urbana. 13 a 18 de setembro de 1992. Vitória: ES. P. 29-38. 
CAVALHEIRO, Felisberto et al. Proposição de terminologia para o verde urbano. Boletim Informativo da Sociedade Brasileira de Arborização Urbana, Rio de Janeiro, ano VII, $\mathrm{n}^{\circ} 3$, 1999. Disponível em: <http:// www.geografia.ufpr.br/laboratorios/labs/index.php>. Acesso em: 04 dez. 2009.

GUARARAPES. Entrando na sua História (1928-1994). [S.I]: Comercial Ltda. [1995?]. 120p.

GUARARAPES. Lei Orgânica do município de Guararapes. 1990.

HEIBER, Rafael Figueiredo Duarte. Poluição do ar por veículos automotores e tipos de tempo em áreas metropolitanas: a elaboração de um roteiro metodológico. 2006, 127 f. Dissertação (Mestrado em Geografia) - Instituto de Geociências e Ciências Exatas, Universidade Estadual Paulista, Rio Claro. Disponível em: $<$ http://www.biblioteca.unesp.br/bibliotecadigital/document/?did=3845>. Acesso em: 13 jan. 2007.

KLUTHCOVSKY, Ana Cláudia Garabeli Cavalli; TAKAYANAGUI, Ângela Maria Magosso. Qualidade de vida - aspectos conceituais.Revista Salus. Guarapuava(PR): Unicentro.. Jan/jun 2007. p. 13-15. Disponível em: http://www.observatorionacionaldoidoso.fiocruz.br/biblioteca/_artigos/12.pdf. Acesso em: 16 abr. 2011. LOMBARDO, Magda Adelaide. Ilha de calor nas metrópoles: o exemplo de São Paulo. São Paulo: Hucitec, 1985. 244p.

MACHADO, Lucy Marion Calderini Philadelpho. Qualidade ambiental: indicadores quantitativos e perceptivos. In: Indicadores ambientais. Coordenação de Nilson Borlina Maia, Henry Lesjak. Sorocaba: s.n., 1997. p. 15-21.

MONTEIRO, Carlos Augusto de Figueiredo. Questão ambiental no Brasil (1960-1980). São Paulo: IGEOG/ USP; 1981.133p. (Séries teses e monografias, 42).

MORATO, Rúbia Gomes et al. Geografia da desigualdade ambiental na Subprefeitura de Campo Limpo, município de São Paulo/SP. In: Anais do XII Simpósio Brasileiro de Sensoriamento Remoto, Goiânia, Brasil, 16-21 abr/2005, INPE. p. 2281-2288.

NUCCI, João Carlos. Qualidade Ambiental e Adensamento: um estudo de Planejamento da Paisagem do Distrito de Santa Cecília. 1996. 229f. Tese (Doutorado). Universidade de São Paulo, São Paulo.

NUCCI, João Carlos. Qualidade ambiental e adensamento urbano. São Paulo: Humanitas/FAPESP, 2001. 236p.

NUCCI, João Carlos; CAVALHEIRO, Felisberto. Cobertura vegetal em áreas urbanas - conceito e método. Revista GEOUSP n.6, 1999, São Paulo. p. 29-36.

POMPÊO, César Augusto. Drenagem urbana sustentável. Revista Brasileira de Recursos Hídricos. Associação Brasileira de Recursos Hídricos: Porto Alegre. Volume 5, nº 1, 2000. p 15-23.

TUCCI, Carlos Eduardo Morelli. Drenagem urbana. Revista Ciência e Cultura, vol. 55, nº 4, São Paulo, out/dez. 2003.

Trabalho enviado em fevereiro de 2012 Trabalho aceito em março de 2012 